\title{
The discovery of male Caligus brevicaudatus Scott, 1901 (Copepoda: Caligidae) parasitic on tub gurnard, Chelidon- ichthys lucerna (Linnaeus) from the eastern Mediterranean
}

\author{
İbrahim Demirkale ${ }^{1}$, Argun Akif Özak ${ }^{1,2}$ and Geoffrey Allan Boxshall ${ }^{2}$ \\ ${ }^{1}$ Department of Fish Diseases \& Aquaculture, Faculty of Fisheries, University of Cukurova, Adana, Turkey; \\ ${ }^{2}$ Department of Life Sciences, The Natural History Museum, London, UK
}

\begin{abstract}
Caligus brevicaudatus Scott, 1901, a common but poorly known species of parasitic copepod, is redescribed from newly collected specimens of both sexes. The new material was collected from the body surface of tub gurnards, Chelidonichthys lucerna (Linnaeus), caught in eastern Mediterranean waters off the Turkish coast. Inadequately described female structures from earlier descriptions are redescribed and illustrated in detail and the male of $C$. brevicaudatus is described for the first time. The new material of C. brevicaudatus is compared with material collected by A. Scott and stored in the collections of the Natural History Museum, London. In addition, a voucher specimen of Caligus uranoscopi Vaissière, 1955, stored in the collections of the Muséum National d'Histoire Naturelle in Paris is re-examined. Caligus uranoscopi is recognised as a junior subjective synonym of C. brevicaudatus since it does not differ in any substantive characters.
\end{abstract}

Keywords: Crustacea, ectoparasite, marine fish, Mediterranean Sea, redescription

The Caligidae is the most species-rich family within the copepod order Siphonostomatoida and Caligus Müller, 1759 is the largest genus, currently containing approximately 250 valid species (Hayes et al. 2012). Caligus brevicaudatus Scott, 1901 is one of a group of only 11 species that share the possession of a two-segmented fourth exopod carrying three unequal distal spines and no lateral spine, in combination with a one-segmented abdomen (less than the half length of the genital complex) in the female (Table 1). Four of these eleven species, C. brevicaudatus, C. kalumai Lewis, 1964, C. littoralis Luque et Cezar, 2000 and $C$. wilsoni Delamare Deboutteville and Nunes-Ruivo, 1958 are known on the basis of females only (Table 1).

In this paper we present the first description of the male of $C$. brevicaudatus, which we collected from the ventral body surface of tub gurnards, Chelidonichthys lucerna (Linnaeus), captured in northeastern Mediterranean waters off the Turkish coast. Caligus brevicaudatus was first reported as parasitic on grey gurnard, Eutrigla gurnardus (Linnaeus), from Liverpool Bay by Scott (1901). Although subsequent reports of $C$. brevicaudatus have most commonly been from gurnards (family Triglidae), it has also been found on two flatfish species: the bastard halibut, Paralichthys olivaceus (Temminck et Schlegel), and the dover sole, Solea solea (Linnaeus), belonging to the families Paralichthyidae and Soleidae, respectively (Choi et al. 1995, Marques et al. 2009, Özak et al. 2013). Since its original description, the morphology of C. brevicaudatus has been redescribed or revisited by various authors (Scott and Scott 1913, Scott 1929, Kabata 1979, Choi et al. 1995, Benmansour and Ben Hassine 1998, Ramdane et al. 2010, Özak et al. 2013). Despite all these earlier studies there are still new morphological details of female $C$. brevicaudatus that have been incompletely documented and the male of C. brevicaudatus has not been previously described.

As redescribed here, C. brevicaudatus closely resembles C. uranoscopi Vaissière, 1955 reported from Chelidonichthys lucerna (as Trigla lucerna Linnaeus), Uranoscopus scaber Linnaeus and Mullus barbatus Linnaeus collected in Mediterranean waters off the Algerian coast (Vaissière 1955, Ramdane et al. 2010). A comparative study of C. brevicaudatus and a voucher specimen of C. uranoscopi, collected by Ramdane et al. (2010) and stored in the collections of the Muséum National d'Histoire Naturelle in Paris (MNHN-Cp6048), is also presented.

\section{MATERIALS AND METHODS}

During a one-year (1. 12. 2012-1. 12. 2013) parasitological survey, tub gurnards, Chelidonichthys lucerna, were caught monthly by bottom otter trawl at depths ranging from $40-50 \mathrm{~m}$ in Iskenderun Bay, near Yumurtalık (36 $\left.42^{\prime} 02^{\prime \prime} \mathrm{N} ; 35^{\circ} 48^{\prime} 34^{\prime \prime} \mathrm{E}\right)$ and Konacik $\left(36^{\circ} 23^{\prime} 39^{\prime \prime} \mathrm{N} ; 35^{\circ} 48^{\prime} 12^{\prime \prime} \mathrm{E}\right)$. The fish $(\mathrm{n}=2700)$ ranged in

Address for correspondence: A.A. Özak, Department of Life Sciences, The Natural History Museum, Cromwell Road, London SW7 5BD, UK. Phone: +44 74402215 81; Fax: +44(0) 207942 5054; E-mail: ozargun@gmail.com or a.ozak@nhm.ac.uk 
Table 1. Species of Caligus Müller, 1785 with short, one-segmented abdomen (less than the half length of genital complex) and two-segmented fourth leg exopod carrying three unequal distal spines and no lateral spine on distal segment.

\begin{tabular}{lcc}
\hline Species & Female & Male \\
\hline C. antennatus Boxshall et Gurney, 1980 & + & + \\
C. balistae Steenstrup et Lütken, 1861 & + & + \\
C. brevicaudatus Scott, 1901 & + & present study \\
C. flexispina Lewis, 1964 & + & + \\
C. kalumai Lewis, 1964 & + & unknown \\
C. littoralis Luque et Cezar, 2000 & + & unknown \\
C. longipedis Bassett-Smith, 1898 & + & + \\
C. minimus Otto, 1821 & + & + \\
C. polycanthi Gnanamuthu, 1950 & + & + \\
C. uranoscopi Vaissière, 1955 & + & + \\
C. wilsoni Delamare Deboutteville et Nunes-Ruivo, 1958 & + & unknown \\
\hline
\end{tabular}

total length from 19 to $25 \mathrm{~cm}$. Parasitic copepods were collected from the anteroventral body surface of the host and immediately preserved in $70 \%$ ethanol. Subsequently, specimens were cleared in lactic acid for $2 \mathrm{~h}$, then dissected on glass-slides and mounted as temporary preparations in lactophenol. Measurements were made using an ocular micrometer and drawings were made with the aid of a drawing tube on an Olympus microscope (Olympus BX 51, Olympus, Japan). All measurements are in millimetres $(\mathrm{mm})$ unless otherwise indicated and are presented as the range followed by the mean in parentheses. All specimens were identified to species level using Scott (1901) and Kabata (1979). The morphological terminology follows Boxshall (1990) and Huys and Boxshall (1991); host fish names are according to FishBase (Froese and Pauly 2015).

Caligus brevicaudatus from Turkey: Fourty-one adult females and three males collected from the anteroventral body surface of the tub gurnard, Chelidonichthys lucerna (Linnaeus), captured in Iskenderun Bay, off Yumurtalık Port, and off Konacik province in Turkey, by Argun Akif Özak; 11 females and 1 male C. brevicaudatus are deposited at the Natural History Museum, London (NHMUK reg. nos 2015.436-445 (ㅇ), 2015.446 (す)); remaining material (thirty females and two males) retained in the personal collection of the second author. The prevalence of $C$. brevicaudatus on C. lucerna was $37.5 \%$ (720 of 2250 hosts parasitized) over the 12-month period of study.

Natural History Museum, London: 32 adult females collected from Chelidonichthys lucerna (Linnaeus) [as Trigla lucerna (Linnaeus)] caught in Luce Bay, Scotland, in 1912 and donated by T. and A. Scott, BM(NH) Reg. Nos 1913.9.18.77-86.

Caligus uranoscopi from Muséum National d'Histoire Naturelle, Paris: female voucher specimen (MNHN-Cp6048) collected from red mullet, Mullus barbatus barbatus (Linnaeus), caught in Algerian coastal waters and donated by Ramdane et al. (2010).

\section{RESULTS}

\section{Caligus brevicaudatus Scott, 1901}

Figs. 1-3

Description (based on the newly collected Turkish material):

Female. Body (Fig. 1A) comprising caligiform cephalothorax, incorporating first to third pedigerous somites, a small fourth pedigerous somite, genital complex and one-segmented abdomen. Total body length 3.37-4.20
(3.75) $(\mathrm{n}=10)$. Cephalothorax covered by suborbicular cephalothoracic shield provided with conspicuous marginal membrane laterally; shield longer than wide, 1.78-2.27 $\times 1.59-2.01(2.0 \times 1.7)$ and slightly broader posteriorly. Posterior boundary of thoracic zone extending slightly beyond posterior margins of lateral zones. Frontal plates provided with membrane and bearing paired lunules. Fourth pedigerous somite wider than long, 0.11-0.23 $\times$ $0.48-0.62(0.18 \times 0.52)$, forming narrow but distinct zone between cephalothorax and genital complex. Genital complex (Fig. 1A) subrectangular, slightly longer than wide, $1.35-1.51 \times 1.18-1.43(1.45 \times 1.36)$, with rounded anterior corners and slightly concave posterior margin; lateral margins parallel and ornamented with array of 8 small compound sensillae (Fig. 1B) along each side (positions arrowed in Fig. 1A).

Abdomen (Fig. 1C) length about 20\% length of genital complex; wider than long, 0.22-0.37 × 0.29-0.41 $(0.29 \times$ $0.35)$; one-segmented and ornamented with pores, sensillae and patch of spinules. Caudal rami (Fig. 1D) slightly longer than wide, $0.1-0.2 \times 0.07-0.09(0.12 \times 0.08)$, about half length of abdomen, armed with 6 pinnate setae: 3 long setae apically, 1 short inner seta, 2 short but very unequal outer setae. Antennule (Fig. 1E) two-segmented; proximal segment much wider than distal, armed with 25 pinnate setae on anterior and anteroventral surfaces plus 2 unarmed and unequal setae located dorsally (Fig. 1E, arrowed); distal segment cylindrical, armed with 11 setae plus 2 aesthetascs on distal margin (Fig. 1E, arrowheads), and subterminal seta on posterior margin. Antenna (Fig. 1F) uniramous, comprising coxa, subrectangular basis and laterally directed subchela formed by fused endopod and distal claw. Coxa armed with small, blunt, posteriorly directed spinous projection; distal curved claw with 2 setation elements, short spine-like seta proximally and long distal seta. Postantennal process (Fig. 1G) acutely curved, carrying 2 papillae each with 4 sensillae; similar multisensillate papilla located on body surface close to base of postantennal process. Mandible (Fig. 1I) of usual form for genus, bearing 12 small teeth on one side near apex. Maxillule (Fig. 1H) comprising anterior papilla carrying 3 unequal naked setae and posterior process with simple slender tine tapering towards tip and small dentiform knob located subterminally. Maxilla (Fig. 1J) two-segmented and brachiform; proxi- 


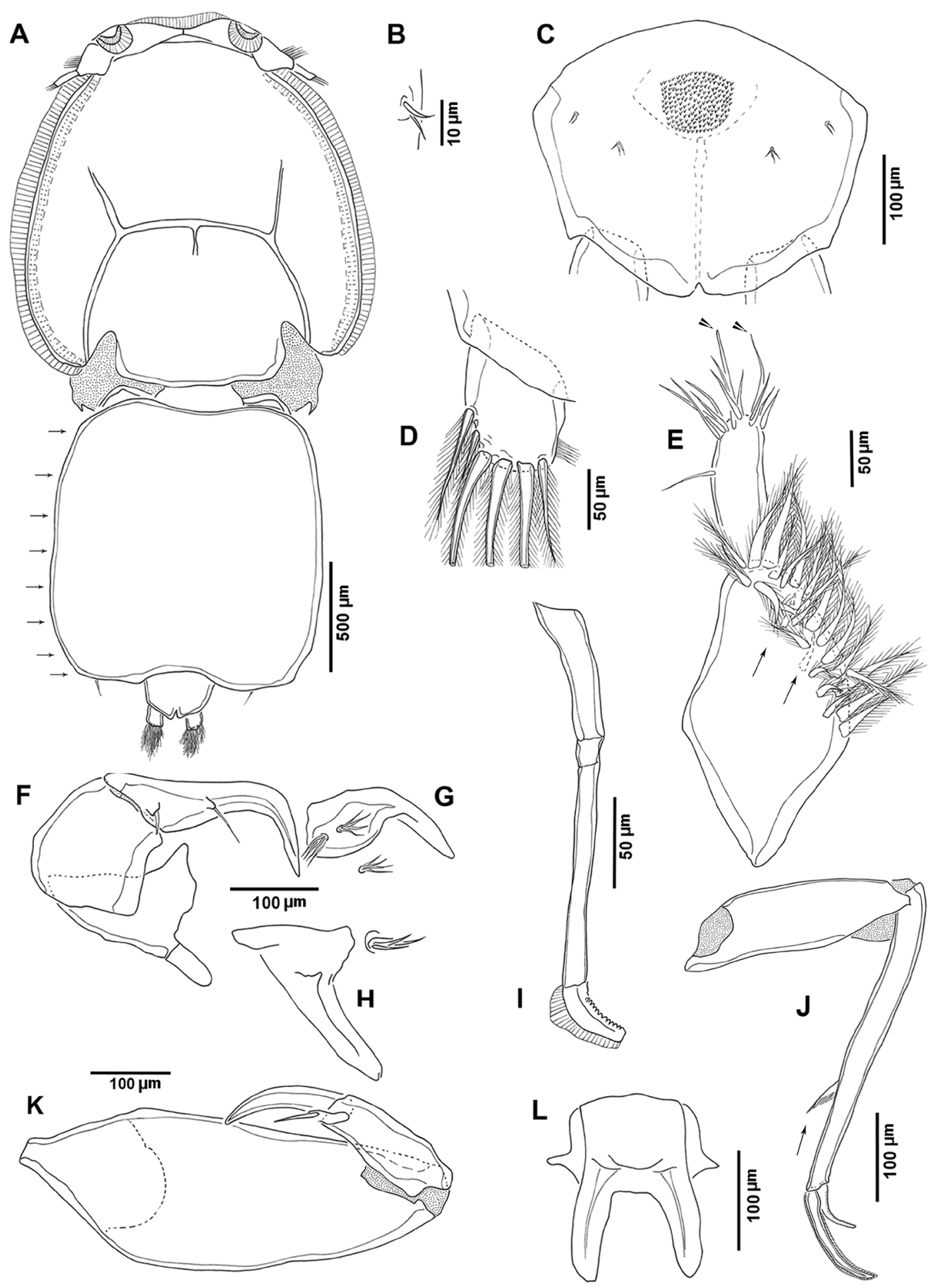

Fig. 1. Caligus brevicaudatus Scott, 1901 from Chelodonichthys lucerna (Linnaeus), female. A - habitus, dorsal view (positions of 8 small compound sensillae arrows); $\mathbf{B}$ - sensillae arrayed along the lateral margins of genital complex; $\mathbf{C}$ - abdomen; D - caudal ramus; $\mathbf{E}$ - antennule ( 2 unarmed dorsal setae - arrows, 2 aesthetascs - arrowheads); $\mathbf{F}$ - antenna; $\mathbf{G}$ - postantennal process; $\mathbf{H}$ - maxillule; $\mathbf{I}$ - mandible; $\mathbf{J}$ - maxilla (hyaline membrane - arrows); $\mathbf{K}$ - maxilliped; $\mathbf{L}$ - sternal furca.

mal segment (lacertus) robust and unarmed; slender distal segment (brachium) with small subterminal hyaline membrane on outer margin (Fig. 1J, arrowed) and tipped distally with 2 unequal processes (calamus and canna); calamus nearly twice as long as canna and bearing 3 strips of serrated marginal membrane running along length; canna with bilateral serrated membranes. Maxilliped (Fig. 1K) com- prising large protopod (corpus) and slender distal subchela comprising endopod plus claw armed with seta slightly more than half length of claw. Sternal furca (Fig. 1L) with slightly diverging tines with blunt tips and square box.

Swimming leg 1 (Fig. 2A) biramous, with two-segmented exopod and vestigial papilliform endopod. Protopod armed with outer pinnate seta located anteriorly, inner 


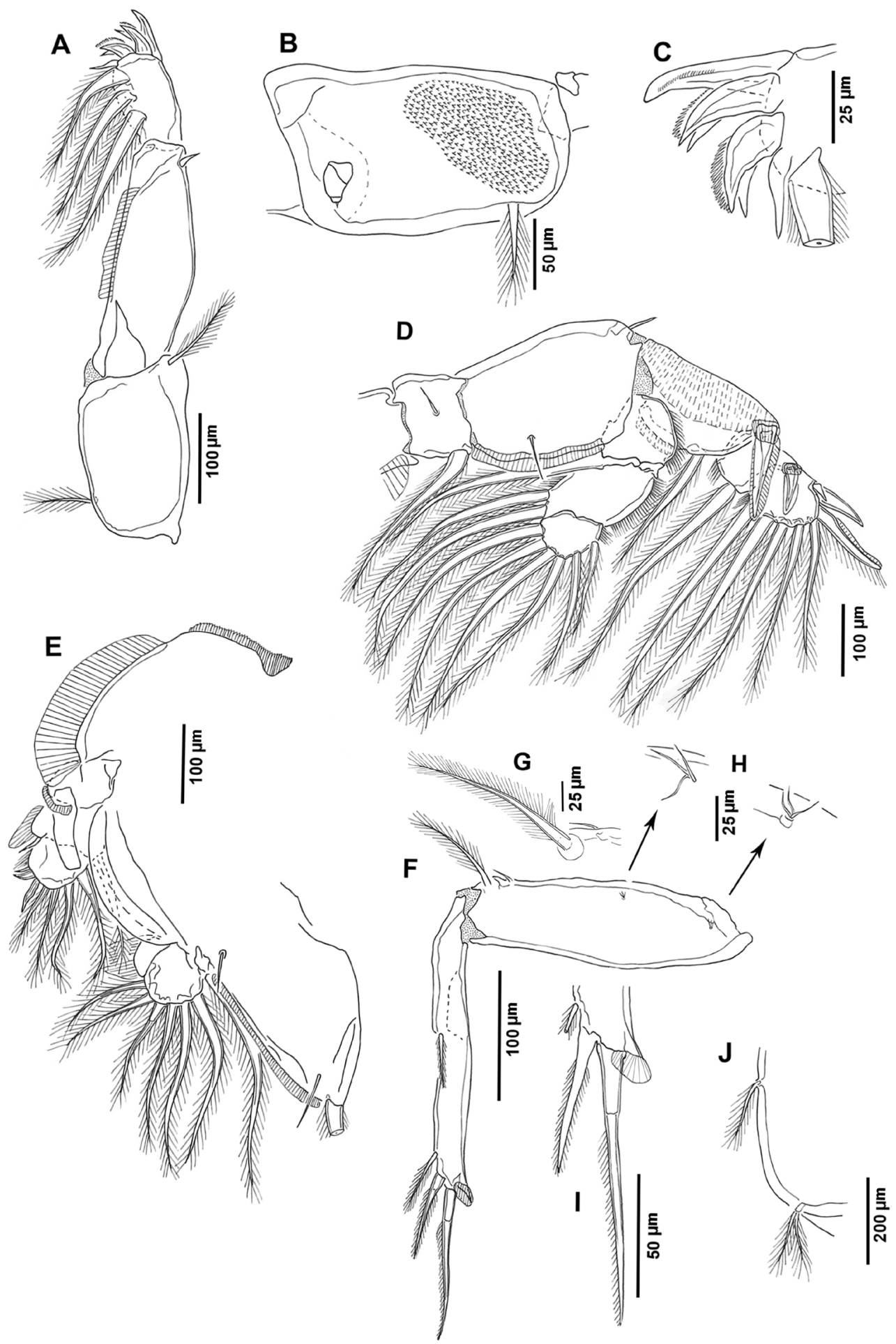

Fig. 2. Caligus brevicaudatus Scott, 1901 from Chelodonichthys lucerna (Linnaeus), female. A - leg 1; B - patch of spinules on coxa of leg $1 ; \mathbf{C}$-terminal spines on distal exopodal segment of leg $1 ; \mathbf{D}-\operatorname{leg} 2 ; \mathbf{E}-\operatorname{leg} 3 ; \mathbf{F}-\operatorname{leg} 4 ; \mathbf{G}-$ seta at outer distal corner of protopod of leg $4 ; \mathbf{H}$ - sensillae on protopod of leg $4 ; \mathbf{I}-$ terminal elements of exopodal segment of leg $4 ; \mathbf{J}-\operatorname{leg} 5$.

pinnate seta posteriorly (both derived from basis) and ornamented with patch of spinules on ventral surface of basal part (Fig. 2B). First exopodal segment with row of setules along posterior margin and carrying small spine at outer distal corner. Distal exopodal segment (Fig. 2C) armed with 3 spiniform elements and one seta on distal margin, plus three pinnate setae on posterior margin; terminal spine at inner distal angle simple and tapering, second and third each with accessory process about half as long as spine and denticulate on anterior margin; outermost seta bearing short setules along one margin. All four terminal elements on distal exopodal segment similar in length and three pinnate setae on posterior margin decreasing in length from proximal to distal.

Leg 2 (Fig. 2D) biramous, with three-segmented rami. Intercoxal sclerite fringed with membrane along free pos- 

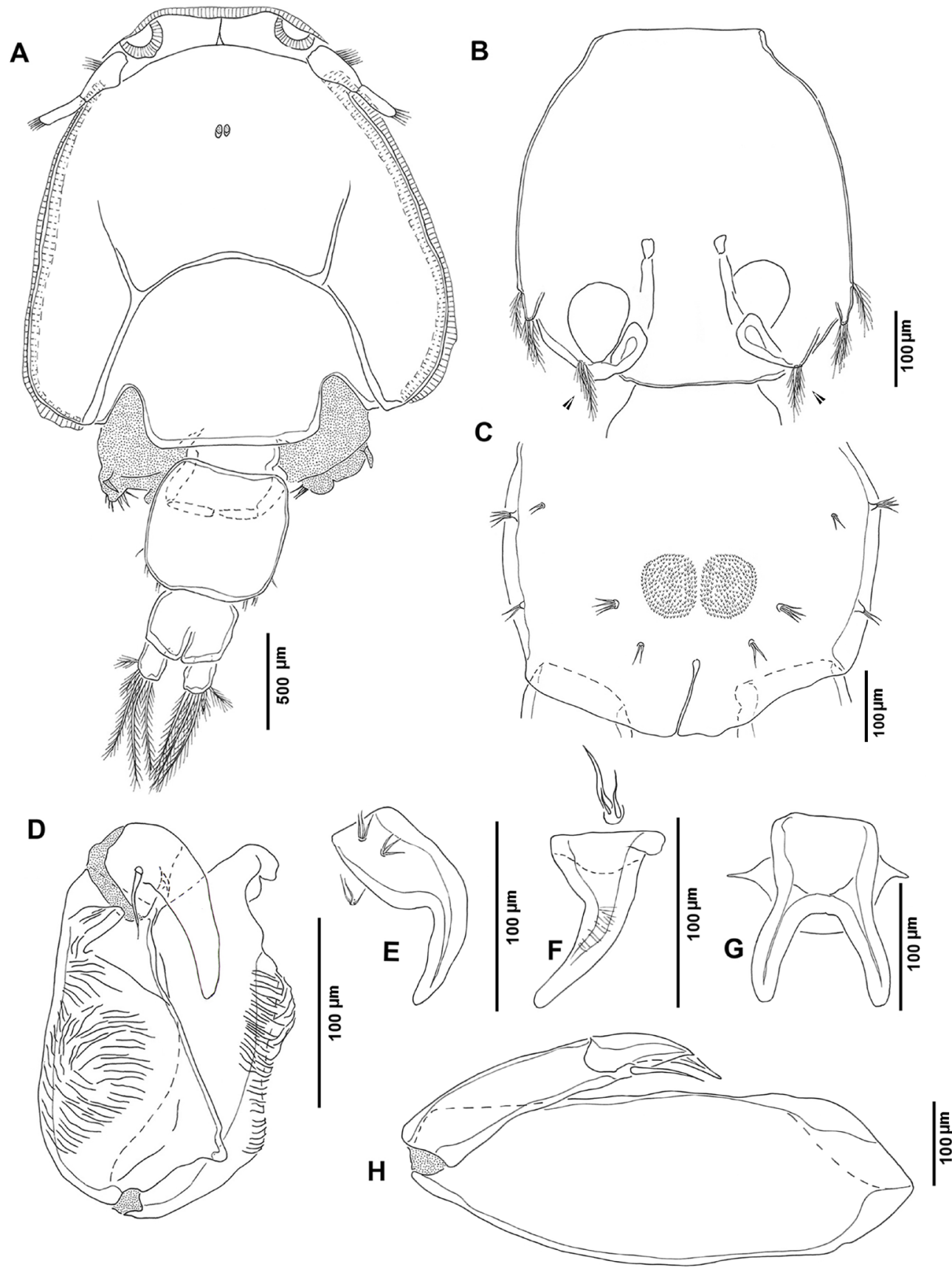

Fig. 3. Caligus brevicaudatus Scott, 1901 from Chelodonichthys lucerna (Linnaeus), male. A - habitus, dorsal view; B - ventral view of genital complex and leg 6 (arrowheads); C - abdomen; D - antenna; E - postantennal process; $\mathbf{F}$ - maxillule; $\mathbf{G}$ - sternal furca; $\mathbf{H}$ - maxilliped.

terior margin. Coxa short, bearing long, pinnate seta on posterior margin and ornamented with single long sensilla on ventral surface. Basis with 1 small spine at outer distal angle, ornamented with long sensilla on ventral surface, extensive flap of marginal membrane attached along free posterior margin and anterior membrane reflexed dorsally over surface of segment. First exopodal segment elongate, with large outer spine reflexed over middle segment, and inner pinnate seta, plus row of setules along inner margin; pecten present at base of outer spine. Dorsally reflexed membrane present along free outer margin of first exopodal segment and extending towards second segment. Second exopodal segment with oblique spine at outer distal corner reflexed over centre of terminal segment and inner pinnate seta, plus tuft of fine setules. Third exopodal segment with small spine proximally with bilateral flanges, adjacent spine with flange on inner margin, terminal spine flanged along outer margin and pinnate along inner, and 5 pinnate setae plus tuft of fine setules proximally and pore on anterodistal corner of ventral surface. Each segment of endopod ornamented with row of fine setules along outer margin; first endopodal segment with long inner pinnate seta; inner margin of second endopodal segment with 2 pinnate setae plus row of setules; third segment with 6 pinnate setae.

Leg 3 (Fig. 2E) forming broad flattened plate as in other species of genus; coxal seta and outer basal seta both 
pinnate. Exopod three-segmented with outer spine on first segment just longer than segment, lying obliquely over surface of second segment and flanged proximally on outer margin. Second exopodal segment armed with outer spine and inner pinnate seta, plus long setules on outer margin. Third exopodal segment with 3 outer spines and 4 pinnate setae. Endopod two-segmented; first segment with inner pinnate seta, second segment armed with 6 pinnate setae.

Leg 4 (Fig. 2F) uniramous. Protopodal segment robust, bearing 1 long pinnate seta on outer distal corner and ornamented with sensillae and pore near outer margin (Fig. 2G,H). Exopod slender and about 1.24 times longer than protopod; two-segmented; first segment carrying 1 distal spine with finely striated membrane bilaterally; second segment with 3 flanged spines along oblique distal margin increasing in length from proximal to distal; longest spine only with pecten at base (Fig. 2I).

Leg 5 (Fig. 2J) represented by 2 seta-bearing papillae located on posterolateral margin of genital complex. Anterior papilla with single pinnate seta; posterior papilla (exopodal) bearing 2 pinnate setae about equal in length.

Spine (Roman numerals) and seta (Arabic numerals) formula of legs 1-4 as follows:

\begin{tabular}{lcc}
\hline & Exopod & Endopod \\
\hline Leg 1 & I-0; III, I, 3 & vestigial \\
Leg 2 & I-1; I-1; II, I, 5 & $0-1 ; 0-2 ; 6$ \\
Leg 3 & I-0; I-1; III, 4 & $0-1 ; 6$ \\
Leg 4 & I-0; III & absent \\
\hline
\end{tabular}

Male. Total body length (Fig. 3A) 1.67-1.95 (1.87) $(\mathrm{n}=3)$; cephalothorax trapezoidal, slightly longer than wide, $1.16-1.2 \times 1.02-1.15(1.17 \times 1.12)$, excluding marginal hyaline membranes. Frontal plates narrow, bearing semicircular lunules. Thoracic zone of shield wider than long, $0.52-0.60 \times 0.68-0.80(0.54 \times 0.71)$; posterior margin of thoracic zone subrectangular and extending slightly beyond boundary of lateral zones. Fourth pedigerous somite wider than long, $0.12-0.16 \times 0.27-0.35(0.14 \times$ 0.31 ) and clearly divided from genital complex. Genital complex (Fig. 3B) narrowing anteriorly, slightly wider than long, $0.38-0.43 \times 0.37-0.45(0.39 \times 0.41)$ with weakly rounded lateral margin and rounded corners. Abdomen (Fig. 3C) one-segmented, about half as long as genital complex, slightly wider than long, 0.20-0.22 × 0.24-0.27 (0.21 $\times 0.25$ ); ornamented with patch of spinules and sensillae as in female. Caudal rami longer than wide, $0.10-0.13 \times$ $0.07-0.09(0.12 \times 0.08)$, armed with 3 short, 3 long pinnate setae; first two outer setae very unequal, as in female.

Antennule as in female. Antenna (Fig. 3D) three-segmented; proximal segment long, armed with adhesion pad on outer surface; middle segment largest, armed with large corrugated adhesion pad produced into small lobe distally; distal segment forming curved claw with rounded tip, armed with 2 slender unequal setae at base, claw about half length of middle segment. Postantennal process (Fig. 3E) curved, with blunt tip, basal part more slender than that of female, ornamented with 2 basal papillae, each with 4 sensillae; similar multisensillate papilla located on body surface close to base of process. Mandible as in female. Maxillule (Fig. 3F) with subtriangular basal part and corrugated pad on middle part of posterior process; anterior papilla with 3 unequal naked setae. Maxilla and sternal furca (Fig. 3G) as in female. Maxilliped (Fig. 3H) with stout protopod (corpus) and distal segment (subchela) with slender shaft and seta bearing claw. Legs $1-5$ as for female. Leg 6 (Fig. 3B, arrowhead) represented by single papilla bearing two unequal pinnate setae.

Remarks. Caligus brevicaudatus was initially reported as parasitic on Eutrigla gurnardus in Liverpool Bay by Scott (1901) and was subsequently reported from Chelidonichthys lucerna in British waters (Scott and Scott 1913, Scott 1929). Caligus brevicaudatus has also been reported from these two hosts from the Barents Sea (Russia), Baltic Sea, North Sea, off the Portuguese Coast, the Gulf of Naples (Italy), the Gulf of Tunis (Tunisia), Kamak Bay (Korea) and from Table Bay (South Africa) (see Özak et al. 2013). In addition, C. brevicaudatus has also been collected on two flatfish species: Paralichthys olivaceus and S. solea (see Choi et al. 1995, Marques et al. 2009, Özak et al. 2013).

The morphological characteristics of the Turkish adult females correspond closely to those presented in the descriptions of C. brevicaudatus given by $\operatorname{Scott}(1901,1929)$, Scott and Scott (1913), Kabata (1979) and Choi et al. (1995). The main similarities are as follows: the orbicular shape of the cephalothorax, the subrectangular shape of the genital complex, the presence of an array of about eight sensillae along the lateral margins of the genital complex, and the short one-segmented abdomen. In addition, the ornamentation of the terminal spines of legs 1 and 4 was also identical.

In 2013, Özak et al. conducted a scanning electron microscopy study of female $C$. brevicaudatus collected from Solea solea (Linnaeus) in the eastern Mediterranean. Our females from $C$. lucerna are very similar to those collected from $S$. solea, but they have slightly smaller mean body length, $3.75 \mathrm{~mm}$ vs $3.82 \mathrm{~mm}$ (from $S$. solea - Özak et al. 2013). These dimensions are smaller than those reported for C. brevicaudatus from Korea $(4.06 \mathrm{~mm})$ and Britain $(5.30 \mathrm{~mm})$ (Scott 1901, Choi et al. 1995). They are also smaller than the newly measured mean total body length of Scott's females $(4.48 \mathrm{~mm})$ stored in the collections of the Natural History Museum, London (BMNH 1913.9.18.77-86), but we infer that the smaller size of the Mediterranean specimens may reflect the difference in temperature regimes.

Males were known for seven of the species listed in Table 1. Caligus antennatus Boxshall et Gurney, 1980, C. balistae Steenstrup et Lütken, 1861, C. flexispina Lewis, 1964, C. longipedis Bassett-Smith, 1898, C. minimus Otto, 1821, C. polycanthi Gnanamuthu, 1950 and C. uranoscopi Vaissière, 1955. The male of $C$. brevicaudatus can be readily distinguished from six of these species. The male of $C$. antennatus differs from the male of $C$. brevicaudatus in having a two-segmented abdomen ( $v s$ one-segmented), elongate caudal rami (4.4 times longer than wide $v s 1.5$ times), and a nodular process on the myxal surface of the maxil- 
liped ( $v s$ without myxal process). The male of $C$. balistae has bilobate posterolateral corners on the genital complex (vs rounded), and a conical process on the myxal surface of the maxilliped ( $v s$ without myxal process).

The male abdomen of $C$. flexispina is two-segmented ( $v s$ one-segmented), the distal segment of antenna terminates in 3 overlapping cuticular flaps (vs slightly curved claw), and the myxal surface of the maxilliped carries a conical process ( $v s$ without myxal process). The abdomen of male $C$. longipedis is indistinctly two-segmented ( $v s$ one-segmented) and there is a corrugated process on the myxal surface of the maxilliped ( $v s$ without myxal process).

The distal segment of antenna of male $C$. minimus terminates in two spiniform processes ( $v s$ a slightly curved claw), the sternal furca has a long and slender box ( $v s$ short box), each of the middle two elements on the distal exopodal segment of leg 1 bears a sharply-pointed tiny spiniform apical process and is ornamented with tiny denticles (vs lacking spiniform process and ornamented with fine serrations along inner and outer margins).

Finally, the abdomen of male C. polycanthi is two-segmented ( $v s$ one-segmented), the postmaxillary process is covered with a corrugated pad ( $v s$ without a postmaxillary process), there is a double knobbed myxal process on the medial surface of the maxilliped ( $v s$ without myxal process), and the posterolateral corners of the genital complex are bilobate ( $v s$ rounded).

Our comparative study revealed numerous close similarities between C. brevicaudatus and C. uranoscopi as described by Vaissière (1955) and Ramdane et al. (2010). The original description of $C$. uranoscopi by Vaissière (1955) was based on material from tub gurnard, C. lucerna (reported as Trigla lucerna) and stargazer, Uranoscopus scaber, from the coast of Algeria. Subsequently, C. uranoscopi was redescribed based on three newly collected females found on red mullet, Mullus barbatus Linnaeus, by Ramdane et al. (2010), also from Algeria. According to Ramdane et al. (2010), C. uranoscopi can be distinguished from $C$. brevicaudatus by having a sternal furca with diverging, blunt-tipped tines and a leg 4 with a slender exopod that is distinctly longer than the protopod.

However, these two key diagnostic characters are the same as those reported by Scott (1901), Scott and Scott (1913) and Kabata (1979) as the distinguishing characteristics of $C$. brevicaudatus. Our comparative study of C. brevicaudatus and C. uranoscopi revealed that both species have sternal furca with diverging, blunt-tipped tines (Fig. 1L). Re-measurements and comparison of the length of the two-segmented exopod with the length of the protopod in leg 4 also confirmed that in both species the two-segmented exopod is about 1.1 to 1.3 times longer than the protopod.

In addition to these two characters, there are other diagnostic features that were not previously compared by Ramdane et al. (2010). We observed that both C. brevicaudatus and the voucher specimen of $C$. uranoscopi shared: (a) a genital complex with distinctive ornamentation of about 8 compound sensillae arrayed along the lateral mar- gins (Figs. 1A,B; see fig. 481 in Kabata 1979 and fig. 1B in Özak et al. 2013); (b) the distal exopodal segment of leg 1 carried four equal terminal spines and the middle two spines both possessed accessory processes (Fig. 2C; see fig. 485 in Kabata 1979, fig. 2B in Özak et al. 2013 and fig. 3B in Ramdane et al. 2010); (c) the caudal rami each carry 6 pinnate setae and the outermost seta is about twice as long as the adjacent seta (Fig. 1D; see fig. 1D in Özak et al. 2013). However, it is important to note here that drawings of these two outer seta on the caudal rami given in Ramdane et al. (2010: fig. 4A) do not match with the voucher specimen stored in the collections of Muséum National d'Histoire Naturelle in Paris.

The measurements of the voucher female of $C$. uranoscopi and the Turkish specimens of $C$. brevicaudatus are as follows: mean total body length $3.84 \mathrm{~mm}$ (vs $3.75 \mathrm{~mm}$ ); cephalothorax $2.08 \times 1.74 \mathrm{~mm}(v s 2.0 \times 1.7 \mathrm{~mm})$; fourth pedigerous somite $0.12 \times 0.36 \mathrm{~mm}(v s 0.18 \times 0.52 \mathrm{~mm})$; genital complex $1.44 \times 1.36 \mathrm{~mm}(v s 1.45 \times 1.36 \mathrm{~mm})$; abdomen $0.29 \times 0.40 \mathrm{~mm}(v s 0.29 \times 0.35 \mathrm{~mm})$; caudal rami $0.11 \times 0.09 \mathrm{~mm}\left(v_{s} 0.12 \times 0.08 \mathrm{~mm}\right)$.

We also compared the newly discovered male of C. brevicaudatus with the male of C. uranoscopi illustrated by Vaissière (1955). The male C. uranoscopi is similar to the male $C$. brevicaudatus as described here based on general body form, with a trapezoidal cephalothoracic shield, quadrangular genital complex with rounded corners, and the short, one-segmented abdomen narrowing anteriorly. The shape of the sternal furca (Fig. 3G), which is also similar to that of the female, the absence of a myxal process on the protopod of the maxilliped (Fig. $3 \mathrm{H}$ ), and the presence of a single curved claw on the apex of the antenna are also identical in both species. It is not possible to compare the setation of the legs as the drawings produced by Vaissière (1955) were inaccurate. In addition, the presence of the patch of spinules on the ventral side of the abdomen, which was observed in C. brevicaudatus by Özak et al. (2013), could not be confirmed as the male type material of C. uranoscopi figured by Vaissière (1955) could not be traced.

Based on the results of our comparative study, C. uranoscopi Vaissière, 1955 is recognised as a junior subjective synonym of $C$. brevicaudatus, since it does not differ in any substantive characters from Scott's material and the Turkish material.

\section{DISCUSSION}

Tub gurnard, Chelidonichthys lucerna is one of the most common and economically important species of gurnards for European fishing nations that border the eastern Atlantic Ocean, Mediterranean Sea and Black Sea (Hureau 1986). Tub gurnard has also been considered one of the most promising species for marine aquaculture (Melotti et al. 2000, Dulčić et al. 2001, Roncarati et al. 2013). Despite the abundance and importance of tub gurnard as an economic resource, knowledge of their diseases remains limited. However, tub gurnard serves as host to a rich diversity of parasitic copepods, 15 species in total (Table 2), belonging to three families: Caligidae Burmeister, 1835, Chondracanthidae Milne Edwards, 1840 and Lernaeopo- 
Table 2. Parasitic copepods reported from fish species of the genus Chelidonichthys Kaup, 1873

\begin{tabular}{|c|c|c|}
\hline Hosts & Species & References \\
\hline Chelidonichthys capensis (Cuvier) & $\begin{array}{l}\text { Caligus brevicaudatus Scott, } 1901 \\
\text { Caligus curtus Müller, } 1785 \\
\text { Caligus diaphanus von Nordmann, } 1832 \\
\text { Caligus pelamydis Krøyer, } 1863 \\
\text { Caligus tetrodontis Barnard, } 1948 \\
\text { Charopinus dubius Scott, } 1901 \\
\text { Lernentoma asellina (Linnaeus, 1758) } \\
\text { Medesicaste penetrans Heller, } 1865\end{array}$ & $\begin{array}{l}\text { Heller (1865), Ho (1970), Rhode (1980), } \\
\text { Oldewage and Van As (1989), Oldewage } \\
\text { (1993), Raibaut et al. (1998), Kabata } \\
\text { (2003), Dippenaar (2005) }\end{array}$ \\
\hline Chelidonichthys cuculus (Linnaeus) & $\begin{array}{l}\text { Caligus diaphanus } \\
\text { Caligus elongatus von Nordmann, } 1832 \\
\text { Caligus gurnardi Krøyer, } 1863 \\
\text { Lernentoma asellina }\end{array}$ & $\begin{array}{l}\text { Kabata (1979, 2003), Cressey and Cressey } \\
\text { (1980), Raibaut et al. (1998) }\end{array}$ \\
\hline Chelidonichthys gabonensis (Poll et Roux) & not reported & - \\
\hline Chelidonichthys ischyrus Jordan et Thompson & not reported & - \\
\hline Chelidonichthys kumu (Cuvier) & Caligus rotundigenitalis Yü, 1933 & Ho and Lin (2004) \\
\hline Chelidonichthys lucerna (Linnaeus) & $\begin{array}{l}\text { Acanthochondria triglae Herrera-Cubilla et Raibaut, } 1990 \\
\text { Caligus brevicaudatus } \\
\text { Caligus diaphanus } \\
\text { Caligus coryphaenae Steenstrup et Lütken, 1961) } \\
\text { Caligus gurnardi } \\
\text { Caligus uranoscopi Vaissière, } 1955 \\
\text { Clavellisa emarginata (Krøyer, 1837) } \\
\text { Lernentoma asellina } \\
\text { Medesicaste triglarum Krøyer, } 1863 \\
\text { Parabrachiella bispinosa (von Nordmann, 1832) } \\
\text { Parabrachiella insidiosa (Heller, 1865) } \\
\text { Parabrachiella triglae (Claus, 1860) } \\
\text { Thysanote impudica (von Nordmann, 1832) }\end{array}$ & $\begin{array}{l}\text { Krøyer (1863), Scott and Scott (1913), } \\
\text { Scott (1929), Oorde de Lint and Schuur- } \\
\text { mans Steekhoven (1936), Barnard (1955), } \\
\text { Vaissière (1955), Markewitsch (1956), } \\
\text { Reichenbach-Klinke (1956), Hamond } \\
\text { (1969), Boxshall (1974), Kabata (1979), } \\
\text { Rhode (1980), Radujkovic and Raibaut } \\
\text { (1987, 1989), Herrera-Cubilla and Raibaut } \\
\text { (1990), Choi et al. (1995), Benmansour } \\
\text { and Ben Hassine (1998), Raibaut et al. } \\
\text { (1998), Benkirane et al. (1999), Palm et } \\
\text { al. (1999), Öktener and Trilles (2004), } \\
\text { Marques et al. (2006, 2009), Özak et al. } \\
\text { (2013) }\end{array}$ \\
\hline Chelidonichthys obscurus (Walbaum) & $\begin{array}{l}\text { Acanthochondria triglae } \\
\text { Caligus brevicaudatus } \\
\text { Parabrachiella bispinosa } \\
\text { Parabrachiella triglae }\end{array}$ & Raibaut et al. (1998) \\
\hline Chelidonichthys queketti (Regan) & $\begin{array}{l}\text { Caligus curtus } \\
\text { Parabrachiella supplicans Barnard, } 1955\end{array}$ & Dippenaar (2005) \\
\hline Chelidonichthys spinosus (McClelland) & not reported & - \\
\hline
\end{tabular}

didae Milne Edwards, 1840. In addition to C. brevicaudatus, three other caligids, Caligus coryphaenae Steenstrup et Lütken, 1861 (reported as Caligus elongatus Heegaard, 1943), Caligus diaphanus von Nordmann, 1832 and Caligus gurnardi Krøyer, 1863 have been reported from C. lucerna (see Heegaard 1943, Vaissière 1955, Hamond 1969, Boxshall 1974, Rohde 1980, Radujkovic and Raibaut 1989, Benmansour and Ben Hassine 1998, Raibaut et al. 1998, Palm et al. 1999).

Caligus brevicaudatus collected from Turkish tub gurnards can be readily distinguished from $C$. coryphaenae, C. diaphanus and C. gurnardi in leg 4: it lacks the lateral spine on the compound distal exopodal segment, which is present on all three of these species. Tub gurnard is one of nine species belonging to the genus Chelidonichthys Kaup (Scorpaeniformes, Triglidae) (Table 2). Six of the species have been reported as hosts of parasitic copepods:
C. capensis (Cuvier) hosts eight species, C. obscurus (Walbaum) and C. cuculus (Linnaeus) each host four species, C. queketti (Regan) hosts two and C. kumu (Cuvier) hosts just one. Some of these records are surprising and are in need of confirmation since they may be based on misidentifications. The report of Charopinus dubius Scott, 1901, a parasite known from elasmobranchs, from $C$. capensis (see Oldewage and Van As 1989, Oldewage 1993, Dippenaar 2005) is questionable as is the report of Caligus curtus Müller, 1785, a northern hemisphere parasite of gadiform hosts, from C. capensis and C. queketti (see Oldewage and Avenant-Oldewage 1993, Dippenaar 2005).

Acknowledgements. This research was funded by the Çukurova University Academic Research Projects Unit (Project No. SUF2013BAP2). We would like to thank Danielle Defaye (MNHN, Paris) for making available the voucher specimen of Caligus uranoscopi for study during a visit by one of us (GAB).

\section{REFERENCES}

BARNARD K.H. 1955: Additions to the fauna-list of South African Crustacea and Pycnogonida. Ann. S. Afr. Mus. 43: 1-107.

Benkirane O., Coste F., Raibaut A. 1999: On the morphological variability of the attachment organ of Lernaeopodidae (Copepoda: Siphonostomatoida). Folia Parasitol. 46: 67-75.

Benmansour B., Ben Hassine O.K. 1998: Preliminary analysis of parasitic copepod species richness among coastal fishes of Tunisia. Monitore Zool. Ital. Suppl. 65: 341-344.

Boxshall G.A. 1974: Infections with parasitic copepods in North Sea marine fishes. J. Mar. Biol. Assoc. U.K. 54: 355-372.
Boxshall G.A. 1990: The skeletomusculature of siphonostomatoid copepods, with an analysis of adaptive radiation in structure of the oral cone. Phil. Trans. R. Soc. Lond. B 328: 167-212.

Choi H.S., Hong S.Y., Lee J.M. 1995: Two species of Caligus (Siphonostomatoida, Copepoda) parasitic on marine cultured fishes from Kamak Bay in Korea. Bull. Natl. Fish. Res. Dev. Inst. (Korea) 49: 157-165.

Cressey R.F., Cressey H.B. 1980: Parasitic copepods of mackerel- and tuna-like fishes (Scombridae) of the world. Smithson. Contrib. Zool. 311: 1-186. 
DippenaAR S.M. 2005: Reported siphonostomatoid copepods parasitic on marine fishes of southern Africa. Crustaceana 77: 1281-1328.

Dulčić J., Grubišić L., Katavić I., Skakelja N. 2001: Embryonic and larval development of the tub gurnard Trigla lucerna (Pisces: Triglidae). J. Mar. Biol. Assoc. U.K. 81: 313-316.

Froese R., Pauly D. (Eds.) 2015: FishBase. World Wide Web electronic publication, www.fishbase.org, 01/2015.

HAMOND R. 1969: The copepods parasitic on Norfolk marine fishes. Trans. Norfolk Norwich Nat. Soc. 21: 229-243.

Hayes P., Justine, J.-L., Boxshall G.A. 2012: The genus Caligus Müller, 1795 (Copepoda: Siphonostomatoida): two new species from reef associated fishes in New Caledonia, and some nomenclatural problems resolved. Zootaxa 3534: 21-39.

HeegaArd P. 1943: Parasitic copepods mainly from tropical and Antarctic Seas. Ark. Zool. 34A: 1-37.

Heller C. 1865: Reise der österreichischen Fregatte Novara um die Erde in den Jahren 1857-58-59 unter den Befehlen des Commodors B. von Wuellerstorf-Urbair. Zool. Theil, Band 2, Abtheilung 3, Crustaceen, Vienna, $280 \mathrm{pp}$.

Herrera-Cubilla A., Raibaut A. 1990: Acanthochondria triglae n. sp., copépode parasite des fosses nassales de poissons Triglidae. Crustaceana 59: 82-88.

Ho J.S. 1970: Revision of the genera of the Chondracanthidae, a copepod family parasitic on marine fishes. Beaufortia 17: 105-218.

Ho J.S., Lin C.L. 2004: Sea Lice of Taiwan (Coepoda: Siphonostomatoida: Caligidae). The Sueichan Press, Keelung, Taiwan, $388 \mathrm{pp}$.

Hureau J.C. 1986: Triglidae. In: P.J.P. Whitehead, M.L. Bauchot, J.C. Hureau, J. Nielsen and E. Tortonese (Eds.), Fishes of the North Atlantic and the Mediterranean. Vol. 2. UNESCO, Paris, pp. $1230-1238$.

Huys R., Boxshall G.A. 1991: Copepod Evolution. The Ray Society, London, $468 \mathrm{pp}$

Kabata Z. 1979: Parasitic Copepoda of British Fishes. The Ray Society, London, $468 \mathrm{pp}$.

Kabata Z. 2003: Copepods Parasitic on Fishes. Second revised edition. Synopses of the British Fauna No. 47. Backhuys, Oegstgeest-Leiden, No. 47: 1-274.

Krøyer H. 1863: Contribution to the knowledge of parasitic copepods. Naturh. Tidsskr. 2: 75-426+ Pls. 1-18.

Markewitsch A.P. 1956: Parasitic Copepodes [sic] on the Fishes of the USSR. Ind. Natl. Sci. Doc. Centre, New Delhi, 445 pp.

Marques J.F., Santos M.J., Cabral H.N. 2006: Soleidae macroparasites along the Portuguese coast: latitudinal variation and host parasite associations. Mar. Biol. 150: 285-298.

Marques J.F., Santos M.J., Cabral H.N. 2009: Zoogeographical patterns of flatfish (Pleuronectiformes) parasites in the northeast Atlantic and the importance of the Portuguese coast as a transitional area. Sci. Mar. 73: 461-471.

Melotti P., Barbaro A., Roncarati A., Mordenti O., GenNARI L. 2000: Definition of induced reproduction techniques of Trigla lucerna L., a Mediterranean species of interest to aquaculture. In: G. Enne and G.F. Greppi (Eds.), Proceedings of the 33th International Symposium on New Species for Mediterranean Aquaculture, Alghero, April 1998, Elsevier, Paris, pp. 61-71.

ÖKtener A., Trilles J.P. 2004: Three new parasitic copepod species for the parasite fauna of marine fish of Turkey. J. Black Sea/ Medit. Environ. 10: 71-80.

OldewaGe W.H. 1993: Occurrence and distribution of copepod fish parasites on the west coast of South Africa. J. Afr. Zool. 107: 413-418

Oldewage W.H., Avenant-Oldewage A. 1993. Checklist of the parasitic cCopepoda (Crustacea) of African fishes. Ann. Mus. Roy. Afr. Centr. Doc. Zool. (Tervuren, Belgium) 23: 1-26.

Oldewage W.H., Van As J.G. 1989: Occurrence and distribution of Caligus (Copepoda: Siphonostomatoida) in African coastal waters. Rev. Zool. Afr. 103: 91-98.

von Oorde De Lint G.M., SchuUrmans Stekhoven J.H. 1936 Copepoda parasitica. Tierw. Nord Ostsee, Leipzig 31: 73-197.

ÖZak A.A., Demirkale İ., Boxshall G.A., Etyemez M. 2013: Parasitic Copepods of the common sole, Solea solea (L.), from the eastern Mediterranean coast of Turkey. Syst. Parasitol. 86: $173-185$.

Palm H.W., Klimpel S., Bucher C. 1999: Checklist of Metazoan Fish Parasites of German Coastal Waters. Ber. Inst. Meereskd. Christian-Albrechts-Univ. Kiel, 307, 148 pp.

Radujkovic B.M., Raibaut A. 1987: Copépodes parasites des poissons des côtes du Monténégro (Adriatique sud). Première série. Acta Adriat. 28: 121-142.

Radujkovic B.M., Raibaut A. 1989: Parasites des poissons marins du Monténégro: copépodes. Acta Adriat. 30: 237-278.

Raibaut A., Combes C., Benoit F. 1998: Analysis of the parasitic copepod species richness among Mediterranean fish. J. Mar. Syst. 15: 185-206.

Ramdane Z., Trilles J.P., Ho J.S. 2010: Caligus uranoscopi Vaissière, 1955 (Copepoda, Caligidae), a rare parasitic copepod from Algeria. Acta Parasitol. 55: 379-385.

Reichenbach-Klinke H.H. 1956: Vorlaufige Mitteilung über die Parasiten der Fisch des Golfes von Neapel. Pubbl. Staz. Zool. Napoli 30: 115-126.

RoHDE K. 1980: Comparative studies on microhabitat utilization by ectoparasites of some marine fishes from the North Sea and Papua New Guinea. Zool. Anz. 204: 27-63.

Roncarati A., D’Andrea M., Pilla F., Felici A., Melotti P. 2013: Tub gurnard Chelidonichthys lucerna L.: a new fish species suitable for farming? First answers evaluating the growth of juveniles reared at different stocking densities, welfare and fillet quality. Aquacult. Res. 44: 1140-1151.

Scott A. 1901: Some additions to the fauna of Liverpool Bay, collected May 1st, 1900, to April 30th, 1901. Proc. Trans. Liverpool Biol. Soc. 15: 342-353.

Scott A. 1929: The copepod parasites of Irish Sea fishes. Proc. Trans. Liverpool Biol. Soc. 43: 81-119+ Pls.1-3.

Sсотt T., Scott A. 1913: The British Parasitic Copepoda. Volumes I and II. The Ray Society, London, $252 \mathrm{pp}$.

VAISSIÈRE R. 1955: Description d'un nouveau copepode parasite: Caligus uranoscopi. Bull. Stn. Aquic. Pèche Castiglione, Nouvelle Série 7: 283-288.

Cite this article as: Demirkale İ., Özak A.A., Boxshall G.A. 2015: The discovery of the male Caligus brevicaudatus Scott, 1901 (Copepoda: Caligidae) parasitic on tub gurnard, Chelidonichthys lucerna from the eastern Mediterranean. Folia Parasitol. 62 : 054. 